\title{
Increasing Kindergarten Students' Vocabulary and Learning Interest Through English Kids Songs at Palembang Paramount School
}

\author{
Arie Fridayanti ${ }^{1 *}$, Tahrun $^{1}$, Mulyadi $^{1}$ \\ ${ }^{1}$ Unversitas PGRI Palembang \\ *Corresponding author.Email: arie_rosid@yahoo.com
}

\begin{abstract}
This research aimed at increasing vocabulary and learning interest of K2B students through songs at Paramount School Palembang. This is classroom action research. The subjects of the research were 9 students of second semester in academic year 2020/2021, consisting of 6 girls and 3 boys. The data were collected through observation and oral test. The data were analysed by using simple statistic calculation to know the mean score or cycle 1 and 2 . The results of data analysis both qualitative and quantitative show that there was an increase in students' vocabulary achievement, and also with their learning interest. It was found that the percentage in first cycle was $54,15 \%$, then there was an increase in the second cycle, which was $86,1 \%$. Based on this result it can be concluded that the use of song as a teaching technique could improve students' vocabulary and learning interest of K2B class kindergarten students at Paramount School.
\end{abstract}

Keywords: Songs, Teaching Technique, Kindergarten Students

\section{INTRODUCTION}

Teaching English to young learners, especially vocabulary, cannot be considered solely a language lesson. Learners' social and cognitive development must be considered during this difficult process. It would be impossible to learn language without vocabulary [7]. Mastering vocabulary in early childhood will be a major point for them to master all aspects of learning English. In Learning English, the students often find problem with memorize the vocabulary, because they feel bored or feels afraid to make mistakes.

At researcher class the students still not able to recognize or remember vocabulary and still feel bored when introducing vocabulary. To solve this problem the teacher have to find the tricks and the method to improve the students learning interest, so their vocabulary will increasing well. To do that, you'll need to build an environment that's close to what children are used to and is anxiety-free. Brain research explains that students will learn easily when they are interested and having fun [5]. To create stronger memories and store it longer, the students have to engage with the activities.

Singing is an enjoyable activity for young children. Songs undoubtedly fall into the category of enjoyable activities that can be used to help students learn a language. They do not place pressure on students to produce the language right away, but rather to wait until they are ready.

To solve the problem, the researcher used English kids songs as a technique to introduce vocabulary. This technique used to attract students' learning motivation especially in creating joyful learning atmosphere. Singing activities are one of the creative techniques in teaching and English learning assistance techniques for early childhood [4], [16],[17]. When the students feels more enthusiasm, and more comfort to mention vocabulary, their confidence and learning interest improving well. It makes them more easier in memorize the vocabulary.

The problems of this study may be formulated as follows, based on the problem's context and identification: "How can English Kids Songs increase kindergarten students' vocabulary and learning interest at Paramount School Palembang?"

\section{THEORETICAL REVIEW}

\section{Kindergarten}

In 1840, Friederich Wilhem Frobel inaugurated an educational institution called Kindergarten. 
Kindergarten actually in Germany means kids garden need to be a sort of training for younger learner that is a transition from home to the commencement of extra formal schooling. Early childhood education is a form of education that focuses on laying the foundation towards growth and 6 (six) developments: religion and morals, physical motor, cognitive, language, socioemotional, and art, in accordance with the uniqueness and stages, development according to the age group passed by early childhood as stated in Permendikbud 137 of 2014 concerning National Standard for Early Childhood Education (replacing Permendiknas 58 of 2009).

Early childhood is a child who has characteristics like to move, has high curiosity, can express himself creatively, has imagination, and likes to talk [3]. Teaching children are often a true adventure to teachers. Imagine a tougher age-group, which might request such a lot creativity, patience, ingenuity. Through the years of teaching them, I realized if I wanted my teaching to achieve success I had to become like one among those little kids [6] . Not in behavior, of course, but in spirit. In order to arouse their interest and make them wanting to learn a far off language at such a young age, we should always understand who they're. About they thought, they behavior, their brain function, and how to assimilate new knowledge.

Concept of Vocabulary

The vocabulary that the child learns for the first time is words that have no martophonemic addition, both in the process of affixing, repetition, and word compounding [15]. Vocabulary development is an important part of every student's life because it influences his or her thoughts, actions, aspirations, and, in many cases, success [10]. It can be concluded that vocabulary It can be concluded that vocabulary is all words contained in a language, understood and used by a person or group of people, used in a science accompanied by an explanation so that it can be understood.

Vocabulary skills are essential to putting together a student's confidence in reading and writing, and therefore the right activities can help get students excited about learning. To effectively acquire English vocabulary, students must follows four essential stages:

First, they notice a new word with help. Secondly, they recognize the word initially with help. Then, they recognize it later on their own. Lastly, they're ready to both recognize and produce the word [1].

Concept of Songs

A song may be a quite musical expression within the sort of spoken and written words. Good music and song in many variation serve many purposes. There are many benefits obtained from listening to songs, for example, children can learn to develop language skills by enriching vocabulary obtained from songs, besides that children can also develop analysis functions [8].
English songs provide variation and interest in learning English and make interesting atmosphere in school [13]. In other words using English songs can provide the learners with an exciting and creative experience of conveying words or expression of the English language. Apply the music or songs appropriately in learning English, will makes the students able to achieve the desired.

Teaching techniques must be creative, attractive, appropriate to the child's development and easy to do, one of the techniques is song [9]. The song also can be useful in making the classroom more interactive.

Singing with your student is not just fun, but it's also helpful because it can help them improve in a number of ways. You will help your students develop language and communication skills, promote engagement, aid in learning academic concepts, encourage self-expression, improve self-esteem, relax, and create routines by singing with them [11]. But there are aspect that must be considered, we must pay attention to the developmental and your students speech level. the lower level, the simpler the song should be.

\section{METHODS}

This research used Classroom Action Research. Classroom action research is an activity carried out by educators or collaborating with other people which aims to improve or improve the quality of the learning process in the classroom [12]. Therefore, classroom action research is closely related to the problems of daily learning practices experienced by educators.

The purpose of Classroom Action Research is to improve the quality of the learning process, so the activities carried out must be in the form of actions that are believed to be better than usual activities [14]. in other words, the actions given to students must be seen to be more effective, efficient, creative, and innovative to provide satisfactory results.

The researcher used 2 cycles for this research. Teacher is possible to find a new problem or the previous unfinished problems yet after applying first cycle. If it happens, it is necessary to do same way to submit the second cycle. The four broad phases in this research cycle are planning (for doing the research), implementing/ acting (application), observing (to see how the process of the treatment), reflecting (study what the students have done and affect the students' improvement).

All of these steps have been carried out by researchers in each cycle in order to increase students' vocabulary and interest in learning. Researchers use songs as a teaching technique that can create a more attractive classroom atmosphere and make students more active during the learning process. supporting media used, namely:

The researcher used 2 media in teaching vocabulary by using English kids songs. The media are you tube application, and flash card or picture. 
This is a descriptive qualitative research project. Qualitative research is a research method based on the positivist philosophy that is used to examine the state of a natural object (rather than an experiment) with the researcher as the primary instrument. Positive and snowball sampling of data sources were used, as well as triangulation (combined) data collection methods. Interpretation and data were inductive / qualitative, and the findings of qualitative study stressed context rather than generalization[3]. As for the subjects used in this study were the principal and class teachers of SD Negeri 1 Rantau Sialang as many as 5 (five) people. Where teachers are educators, teachers, as well as respondents or research informants in this study. The techniques in collecting data can be done together, namely observation, interviews and documentation studies [4].

In this study, the following data analysis techniques were used: 1) Data reduction, which is when data is derived from a large and complex field and it is important to analyze data through data reduction. Reducing data by summarizing, choosing the most important items, concentrating on the most important items, and deleting the less important items 2) Data is provided in the form of a brief summary in the form of narrative text, i.e. data that has been reduced. The data would be easy to understand as a result of the presentation, making future job plans simpler, 3) Data testing, i.e. drawing conclusions and checking the initial conclusions, is still in the early stages and can change if good supporting evidence is not found. However, if the conclusions made at the beginning are backed by credible and clear evidence when the study team returns to the field to collect data, the conclusions reached are accurate conclusions.

\section{RESULTS AND DISCUSSION}

\section{Results}

Applying teaching techniques using songs actually able to increase the students' vocabulary skills and also student's learning interests. The result of the students assessment gets increasing from the first cycle to the second cycle.

The results of student learning activities in cycle was $54,15 \%$. (Fair Grade) Then, there was a very high increase in the second cycle, which was $86,1 \%$ (Excellent Grade) from the first cycle there is an increase of $31 \%$. This result shows that the students' vocabulary increased student vocabulary has increased due to the increase in student learning interest during learning activities with the use of songs as a technique.

The following is a table of the results of the observation assessment cycle 1 and cycle 2 which describes students' learning achievement from two observations: 1. Teaching-learning process, 2. Student's Assessment.
Table 1 Summary of Pupils' Improvement

\begin{tabular}{ccc}
\hline OBSERVATION & CYCLE I & CYCLE II \\
\hline Teaching Learning Process & 62,2 & 88,25 \\
Students 'Assessment & 54,5 & 86,1 \\
& $\underline{116,7}=$ & $\underline{174,35}=$ \\
Mean & 2 & 2 \\
& $\mathbf{5 8 , 3 5}$ & $\mathbf{8 7 , 1 7 5}$ \\
\hline
\end{tabular}

\section{Discussion}

Related to the findings, English kids song as a teaching technique could increase kindergarten students' vocabulary. Application of this teaching technique in learning vocabulary can run well, it can be seen from the teacher's ability to manage learning that has increased from cycle I, and II. This has a positive effect on the progress of students' vocabulary and their learning interest that indicated by the increase in the percentage on each observation sheet of the teacher's ability to manage learning done by the collaboration teacher, namely from cycle I and cycle II.

a. for the result score of the observation sheet of teaching and learning process there is significant improvement : cycle I: 62,2 (fair grade), cycle II: 88,25 (excellent grade)

b. for the result of the observation sheet of students' assessment there is also an improvement from each cycle: cycle I: 54,5 (fair grade), and the cycle II: 86,1 (excellent grade).

c. these are the result of pupil's capability in answering the questions given orally from each cycle: cycle I: 40,85 (poor grade), cycle II: 68,8 (fair grade), cycle III: 87,25 (excellent grade).

According Febrianto (2020) says that one of the most effective techniques or ways of learning English is through songs, because it is proven to quickly help children master a lot of vocabulary. Based on the result above, when researcher using songs as a teaching method for teaching English The students feels more enthusiasm, and more comfort to mention vocabulary, their confidence and learning interest improving well. It makes them more easier in memorize the vocabulary.

\section{CONCLUSION}

Based on the description of the results of research carried out on cycle 1 and cycle 2 can be concluded learning through songs as teaching technique can increase the vocabulary and learning interest in kindergarten students at Paramount School. Based on 
the result of the study, the researcher has some suggestions to the following parties.

1. The Students

The result of the research indicates that the $\mathrm{K} 2 \mathrm{~B}$ students' vocabulary and learning interest at Paramount School Palembang is increased. Hopefully the students will be more confidence, and always enjoys during follows the lesson activities especially in memorizing the vocabulary.

2. The Teachers

The use of songs as a teaching technique can create a class atmosphere more enjoyable, stress free and interesting for students. It can be an alternative in learning process to increasing the students' vocabulary and the students' learning interest, and to motivated the students to speak English. Hopefully, this technique also can be apply to other subjects not only in English.

3. Other Researchers

This research can be used as a reference for researching other fields besides vocabulary, so it can help to improve the quality of our students' education.

\section{REFERENCES}

[1] Claudia Pesce. Teaching English Vocabulary 10 Fabulous Ways To Teach New Words https://busyteacher.org/2921-teaching-englishvocabulary-10-fabulous-ways-to.html [acsess:January $12^{\text {th }} 2021$

[2] Febrianto,A.R. Belajar Bahasa Inggris dari Para Cendikiawan dan Profesional Sukses.Jakarta: EMedia Member of Guepedia Group. 2020

[3] Guslinda,et.al. Media Pembelajaran Anak Usia Dini. Surabaya: Jakad Publishing. 2018

[4] Hartono,H. Metode dan Teknik Kreatif Mengajar Bahasa Inggris untuk Anak-Anak Usia Dini. Semarang:Universitas Katolik Soegijapranata.2020.

[5] Jones, T. Fifty Ways to Teach Vocabulary. United States: Waygoose Press. 2018.

[6] Katalin Nagy, Școala Gimnazială „Mihai Eminescu" Zalău. Teaching vocabulary to young Learner Using Songs and Games https://rate.org.ro/blog2.php/1/teaching-vocabularyto-young-learners [access: January $12^{\text {th }} 2021$ ]

[7] Michael F. Graves, D. A. Teaching Vocabulary to English Language Learners. New York: Library of Cataloging. 2013

[8] Monty P. Satiadarma, M. M. Cerdas Dengan Musik. Depok: Puspa Sehat. 2014

[9] Mohammad, H. M. Easy Reader;Metode Cepat \& Mudah Belajar Membaca Bahasa Inggris. Jakarta: Kawan Pustaka. 2009.
[10] O'Rourke, J. P. Toward a Science of Vocabulary Development. Ohio: Mouton\& Co.N.V: Publisher The Hague. 2019.

[11] Ott, P. Musical Activities, Songs,Instrument and Resources. Philadephia: Jessica Kingsley Publisher. 2011.

[12] Parnawi, A. Penelitian Tindakan Kelas(Clasroom Action Research). Yogyakarta: CV Budi Utama. 2020.

[13] Ratnawati, S. M. A Study of English Songs On Teaching Vocabulary at Kindergarten Students of Lembaga Pendidikan Islam Bustanuddin Galis Pamekasan. Pamekasan: Duta Media Publishing. 2019.

[14] Rusman, A. Classroom Action Research Pengembangan Kompetensi Guru.Purwokerto: Penapersada. 2020.

[15] Usman,M. Perkembangan Bahasa Dalam Bermain dan Permainan Untuk Pendidikan Anak Usia Dini.Yogyakarta: Deepublish. 2015.

[16] Syafryadin, S. 2020. Effective English teaching for young learners classrooms. Yavana Bhasha: Journal of English Language Education, 3(2), 7988.

[17] Martina, F., Syafryadin, J. S., \& Rakhmanina, L. (2020). Novice teacher's pedagogical content knowledge (PCK) in teaching English for young learners. Journal of Critical Reviews, 7(14), 1472 1476. 